\title{
Ethics Education and Training for Construction Professionals in Malaysia
}

\author{
N. Mohamad ${ }^{1}$, H. Abdul Rahman 2 , I. M. Usman ${ }^{3}$ \& N. M. Tawil ${ }^{3}$ \\ ${ }^{1}$ University Technology MARA, Malaysia \\ ${ }^{2}$ International University of Malaya-Wales, Malaysia \\ ${ }^{3}$ University Kebangsaan Malaysia, Malaysia \\ Correspondence: N. Mohamad, Centre of Studies for Quantity Surveying, Faculty of Architecture, Planning and \\ Surveying, University Technology MARA, 40450 Shah Alam, Selangor, Malaysia. E-mail: \\ norsiahmohamad@yahoo.com
}

Received: June 28, 2014 Accepted: November 28, 2014 Online Published: January 14, 2015

doi:10.5539/ass.v11n4p55 URL: http://dx.doi.org/10.5539/ass.v11n4p55

\begin{abstract}
In the attempt to reshape the future landscape of the construction industry in Malaysia, there is a need to address the increasing concern of ethical issues prevailing in the industry. The way forward is to improve ethics in the industry and it should start from the way we educate the construction professionals. This paper discusses the research on the significance of ethics education and training for construction professionals. It underlines construction professionals' perceptions on ethics education and training as a way to improve ethics in the Malaysian construction industry. A questionnaire survey was conducted with construction professionals made up of architects, quantity surveyors and engineers from Malaysian main construction industry players that are the clients, contractors and consultants involved with the design, project management and construction of projects in Malaysia. Results from the survey show that ethics and moral education at elementary school; ethics education for undergraduate levels of construction and engineering programs at colleges/universities; and, professional institutions' responsibility to endorse the ethics substance by conducting Continuing Professional Development (CPD) ethics training for their members, are significant to form the nucleus of the construction professionals' ethical setting to improve ethics in industry. Further research may focus on ethics education specifically in designing appropriate ethics curricula for undergraduate construction and engineering programs in Malaysia.
\end{abstract}

Keywords: ethics, education, training and construction professionals

\section{Introduction}

Construction industry is one of the largest and most valuable industries in Malaysia. It has been playing a major role in economic development in Malaysia and is developing quickly (CIDB, 2005a). Maintaining a high ethical standard of construction professionals and practice is crucial to the continuing healthy development of Malaysia and to the growth of the industry in particular. A high standard of behavior and social responsibility is expected of construction professionals when they exercise their expertise, judgment and supervisory accountability over the management or implementation of a construction project (HKEDC, 2003).

In Malaysia, Construction Industry Development Board (CIDB) in collaboration with the industry's stakeholders has formulated the Construction Industry Master Plan (CIMP) (2006-2015), as part of the national agenda actively to promote ethics in the construction industry. Seven Strategic Thrusts have been identified to ensure efficient execution of the CIMP. The Second Thrust is to "strengthen the construction industry image" (CIDB, 2007, p. 112). The Master Plan has also identified seven critical areas. One of the agenda is: "professionalism-enhancement of professionalism is vital to the improvement of the image of the industry" (CIDB, 2007, p. 78). These efforts share a common goal-to heighten awareness towards the prevention of unethical and malpractices so as to enhance ethics in the construction industry. Ultimately, the underlying principle is to improve service quality delivered by construction players and professions for the good of community interest.

In the face of its size and universality, the construction industry is often cited as plagued with graft and unethical practices. Revelation of research carried on in construction industries in other countries shows evidence that the 
industry is inundated with ethical issues (Vee \& Skitmore, 2003; Jackson, 2004, 2005; FMI/CMAA, 2004; Poon, 2004; Fan \& Fox, 2005; Pearl et al., 2005). Common ethical issues highlighted were tendering practice, sub-standard quality of construction work, safety culture, payment woes, corruption, and most importantly, public accountability for money spent on public buildings and infrastructure. The scenario in the construction industry in Malaysia is no exception. The problems facing the industry are accountability and transparency of management of public funds, public sector procurement and tendering system, the contractors' performance and lack of professionalism, cash flow problem of contractors, lack of self-regulation among contractors and other professional industry players in ensuring ethical practice and continuous improvement, and lack of regulatory approach towards code of ethics of associations and professional bodies (CIDB 2005).

In the attempt to reshape the future landscape of the construction industry in Malaysia and to enable it to achieve its optimum capacity, capabilities and growth potentials, the industry faces a major problem in the area of ethics. There is a need to address the increasing concern of ethical issues prevailing in the industry. The way forward is to improve ethics in the industry and it should start from the way we educate the construction professionals. It is important that the industry not only concentrate on technological advances, but also put ethics in action. Good ethics is the only way to gain the trust and confidence of customers as well as the public and it depends not only on the way we practice construction as to the system, procedure, rules and regulations in the industry; but also on the construction professionals' competency.

The objective of this research is to investigate the significance of ethics education and training for construction professionals to improve ethics in the Malaysian construction industry. In order to provide an understanding on ethics, the literature review will discuss the concepts of ethics with regards to the definition of ethics, professions, professionals and professional ethics. It will then explore ethics education and training in general, with focus on construction professionals.

\section{Literature Review}

\subsection{Concepts of Ethics}

According to Guttman (2006), the purpose of ethics is to acquire mental powers that will enable one to overcome fleeting instincts and passions by means of preferring the general good over the bad; and, to develop oneself to a level at which the decision to be moral or ethical will come from the heart and soul and does not have to be imposed by any outside power. Ethics has been defined as a set of moral values and principles, which form the standards guiding the code of conduct of individuals, organisations and professions (The Institute of Integrity in Malaysia-IIM, 2004); the concept of morals-one's ability to choose between right and wrong, good and bad, acceptable and unacceptable (Velasquez, 2009); and, code of moral principles that sets standards of good or bad, or right or wrong behaviour (Schemerhorn, 2008). Ethical behaviour is what is accepted as good and right as opposed to bad or wrong in the context of the governing moral code (Abuznaid, 2009). Being ethical involves taking action to ensure that these practices and rules are applied consistently in all day-to-day business situations (Orme \& Ashton, 2003).

The professions have always been linked with the notion of service (Vee \& Skitmore, 2003). Its responsibilities have been variously described as including the satisfaction of an indispensable and beneficial social need (Johnson, 1999) and a goal of service to the public (Fryer, 1997). However, the essence of a profession is more than a service since it necessitates specialized knowledge. A profession is special training around a specific body of knowledge leading to an exclusive area of practice, the ideal of being learned, and a duty of social responsibility in how its members carry out their work (Grimshaw, 2001); and, professions are occupations that both require advanced study and mastery of a specialised body of knowledge and undertake to promote, ensure or safeguard some matter that significantly affects others' well-being (Whitbeck, 1998). To put it simply, a profession is a group of people organised to serve a body of specialised knowledge in the interests of society (Appelbaum \& Lawton, 1990); and, are those forms of work involving advanced expertise, self-regulation, and concerted service to public good (Martin \& Schinzinger, 2005).

A professional is an agent who freely makes a public promise to serve persons and is distinguished by a specific desire for a particular good (Koehn, 1994). Professionals are also expected to behave with professional integrity, which include honesty and fairness (Pearl et al., 2005). In order for a professional to command public confidence, two essential elements are essential-professional knowledge and ethical conduct (Chakley, 1994). In Malaysia, construction professionals include architects, quantity surveyors and engineers.

Professionals are usually bound by a set of principles, attitudes or types of character dispositions that control the way the profession is practised (Vee \& Skitmore, 2003). This has been termed 'professional ethics' (McDowell, 1991). It ascribes moral responsibility not to a person in general but to professionals practising in a particular 
profession (Ho \& Ng, 2003). Professional ethics concerns potential problems confronting members of a profession or group in their impact on society, with the implication that fairness should be attributed not only to clients, but also colleagues, and the public (Johnson, 1999). In this sense, professional ethics concerns the morality of the behaviour of professionals in their day-to-day practice.

Even though professional ethics concerns the rightness of behaviour, it is different from ethics (Ho \& $\mathrm{Ng}, 2003$ ), as it can be properly analysed only against a set of social values and a conception of the general role of professions in society (Vee \& Skitmore, 2003). Professional ethics is tied up with more practical concepts and expectations from the public, like competence, responsibility, and willingness to serve the public (HKEDC, 1996). Hence, from the public's perspective, the general normative rules of conduct are now stricter for the professionals.

The building and engineering professionals-engineers, architects, project managers and contractors (including quantity surveyors in Malaysia) have the fundamental right of professional conscience (Martin \& Schinzinger, 1996). Even though the public increasingly demands ethical conduct of everyone involved in business, the public's expectations regarding professional behaviour are higher than their expectations regarding business persons (Jamal \& Bowie, 1995). The ethical element in professional conduct cannot be ignored and the need for professions to be aware of ethical issues in the way they conduct themselves is an important element of their recognition (Grimshaw, 2001).

Ethics needs a structure-they need a policy, a code of practice, or a cultural understanding of the rules (Orme \& Ashton, 2003). However, they also need individuals who can differentiate between right and wrong, people who can make ethical decisions and are assertive enough to make a stand by the decisions they make. Therefore, the significance of ethics education and training especially for professionals cannot be undermined.

\subsection{Ethics Education}

Competency for construction professional comprises two elements-the actual performance of a required skill and the personal attributes which underlie such performance (Birkhead et al., 2000). There is no doubt that technical knowledge in the required areas of a profession is crucial when working in the construction industry. However, Turner and Crawford (1992) asserted that the personal attributes of values and attitudes are more important than actual performance in influencing job success in the industry. They added the contribution that these personal attributes make towards improving performance indicates a growing awareness on the personal characteristics. The importance of individual values, in particular, ethical conduct is an essential element in developing a better practice culture in the construction industry (Fox \& Skitmore, 2003). Chan et al. (2002) emphasised that the inclusion of ethics clearly acknowledges that values and morals are part of competency which enhances professional credibility. However, emphasis of learning for construction professionals is on technical and performance knowledge which is regarded as a necessity, with less consideration on approaches to internalise and establish ethical values and conduct into the professionals.

\subsubsection{Early Education in Ethics}

The quality of ethics can create a stable structure for building personal and professional success of an individual. The question is, do we develop our moral values through experience and education, or are they inherent from our early development? Plato perhaps anticipated this controversy when he asked Socrates whether virtue is acquired through schooling, practice or nature (Halfond, 1990). Abuznaid (2009) proposed that some people believe that moral foundations for deciding what is right and what is wrong are formed in childhood, before even the age of six and eight, and nothing in later life significantly changes this moral foundation. Bishop (1992) contended that early education experiences and family influences are going to have the most impact on the integrity of individuals who will be future business leaders and their willingness and ability to be value driven.

Ethics should not be separated from religion. Law, as well as ethics, was considered inseparable from religion, as every offence represented an act against the name of God (Lewis, 2001). According to Fuchs and Hofkirchner (2003), religious and moral education breeds and enhances individual knowledge and is a constitutive aspect of all social self-organisation. With divine scripture as a guideline, individuals will be helped to take sequential steps toward higher moral reasoning (Rizk, 2008).

Learning the basic principles of ethics constitutes the first stage in the process of knowledge-the key component that shows a person's ethical sensitivity but also generates awareness with regard to the various ethical perspectives and various ethical challenges (Fuchs \& Hofkirchner, 2003). While most moral values are learned in early life, there are several sound reasons why people should continue to study ethics. These reasons include the need to know what to do and decide to do it and personal commitment to choose what is right, and this continues 
to develop as one grows; and, some others believe that the study of ethics will definitely lead to ethical behaviour (Abuznaid, 2009). The following discussion will review the next stage of ethics education in colleges and universities.

\subsubsection{Undergraduate Ethics Education}

Most would admit that professional value, integrity and competence of construction professionals would be developed deeply and firmly during their professional education and training in universities (Chan \& Chan, 2002). Bishop (1992) urged that universities should take a critical look at their role in the ethical development of future professionals and to assume a leadership role in addressing society's conscientious professional decision making and actions. He added that universities should practice what they preach with regard to being responsive to environmental forces as the environmental demand for universities to contribute to ethical practice is being heard in an increasing and resolute voice.

In a survey on future global visions of engineering education by Sunthonkanokpong (2011), high ethical standards and a strong sense of professionalism comes in third ranking out of seven successful attributes for the engineering education graduates in 2020. In the US, the Accreditation Board of Engineering and Technology recommends the study of ethics-so that students acquire an understanding of professional and ethical responsibility (Bucciarelli, 2008). Such concerns should also apply to students in other construction related programs.

Review of the literature examining whether college-level ethics courses and/or courses in which ethics is incorporated into course content have an impact on attitudes towards ethics-shows positive results. However, most ethics courses are conducted in business-related courses such as in business course (Glenn, 1992) and accounting courses (Hiltebeitel \& Jones, 1992; Kerr \& Smith, 1995). The course in business ethics improved students' abilities on recognition of ethical issues (Gautschi \& Jones, 1998). Eynon et al. (1997) found that taking a course in ethics had a significant effect on attitudes towards ethics. With regards to engineering education, teaching engineering ethics can achieve at least four desirable outcomes: i) increased ethical sensitivity; ii) increased knowledge of relevant standards of conduct; iii) improved ethical judgement; and iv) improved ethical will-power (that is greater ability to act ethically when one desires such) (Herkert, 2000). Self and Ellison (1998) also reported significant improvements in the moral reasoning skills of students after they sat in an engineering ethics course.

Egbu (2004) confirms that more is needed on the education and training of construction personnel, which should reflect the nature of ethical scope as a very complex social dimension. The positive outcomes on teaching ethics should initiate colleges/universities of construction-related programs in Malaysia to provide ethics courses in their curriculum. These include programs in architecture, quantity surveying and engineering. The public universities that offer most of these courses are University Technology MARA, University Technology Malaysia, University Malaya, International Islamic University and University Science Malaysia.

In the US and Hong Kong, concerns regarding unethical and malpractices in the construction industry have given rise to the emphasis on the inclusion of ethics in construction curricula (FMI/CMAA, 2004; HKEDC, 2003). Results of a study on ethics by Vee and Skitmore (2003) showed that there is a need to review the provision of professional ethics-related subjects or modules to construction related courses during the academic tenure of the professional to improve the knowledge of professional. Ethics should be studied because it is important, both in contributing to safe and useful technological 'products' and in giving righteous meaning to the construction professionals endeavours (Candace, 2003).

However, education in professional courses at the undergraduate level has always posed a challenge to both educators and to professional bodies since the needs of the professions and the vision of the educators do not necessarily coincide (Chan et al., 2002). The real challenge in teaching ethics to construction students is: i) to provide an introduction to the basic issues in construction issues, with emphasis given to the ethical/moral problems within the construction business setting, ii) to develop a set of moral values and also problem solving technique, and iii) the students must be encouraged to develop a critical judgement rather than merely digesting other views to reach his or her own answers (Robertson, 1987). Nevertheless, the educational setting is an ideal place to teach and practice ethics as this is the environment that helps builds tomorrow's construction society.

Education in ethics serves to establish and reinforce existing values and encourage their application (Bishop, 1992). Clearly, educational institutions cannot accomplish the mission alone. It is unlikely that any educational intervention will result in a complete overhaul of a student's ethics. Therefore, in order to improve professional standards, there is a need to foster an ethical culture by enhancing education on ethics, not only for construction students, but including training of ethics for practitioners (Suen et al., 2007). 


\subsection{Ethics Training}

Learning of ethics should not stop at education in college or university but should be continued during the construction professional's working life. Professionals who are essentially individuals come to work with different values, good and bad, which results in ethical and unethical practices. According to Friedson (1973), one of the first steps in promoting ethical behaviour of professionals is to ensure the leaders of the professional community propound the importance of ethical conduct among its members.

The greatest imperative of professional institutions is their long-term role to ensure the community receives value in the provision of professional services. Public status, maintenance of skills and ethical standards should remain the main objectives of professional institutions. Important characteristics of a professional group are autonomy and discipline and a great capacity for self-development and self-regulation (Bergenhenegouwen, 1996). These are based on a professional statute, which in most cases has the following characteristics: i) providing services to members in order to help them develop their own professionalism, and ii) establishing adequate performance and ethical conduct in a specific profession (Webster, 1991). In Malaysia, these roles are taken up by the professional bodies of Board of Architects, Board of Quantity Surveyors and Board of Engineers, Malaysia, which regulate the conducts and practice of the respective professions.

Apart from technical qualification, a professional also requires ethical normative competence normally acquired through training. Among the solutions suggested by the FMI/CMAA (2004) survey, in order to reduce or prevent unethical practices in the construction industry, is to have more ethics training (Rick, 2005). Training implies certain dealings in which one has to make a choice among various options; and, choosing to solve a certain problem implies formulating a value judgement about the available alternatives-such choices are generally based on ethical decisions (Bergenhenegouwen, 1996).

Continuing Professional Development (CPD) has been increasingly receiving more attention in recent decades, as construction professionals are required to update themselves with new developments in the rapidly changing built environment (E. H. W. Chan, M. W. Chan, Scott, \& A. T. S. Chan, 2002). CPD is a systematic maintenance, improvement and broadening of knowledge and skills, and development of personal qualities necessary for the execution of professional and technical duties throughout a practitioner's working life (RICS, 1993). The implementation of CPD training can be conducted in different approaches-through conferences, workshops, lectures and study for a qualification (Le Roux et al., 2004). Vee and Skitmore (2003) recommended that professional institutions in the construction industry should conduct CPD courses through working forums, discussion, talks and seminars which endorse professional ethics substance.

Ethical issues often occur during the training or working life of a professional; nevertheless, not all professional institutions make it compulsory for their members to attend or enrol in any ethics-related training. CPD is expected to improve the public standing of construction professions (Mills et al., 2005) and serve as a means to develop service attitude and professionalism (Le Roux et al., 2004). Studies by Vee and Skitmore (2003) showed that during the post-working professional training, there is lack of professional ethics-related CPD seminars to complement the pre-work ones. Nevertheless, professionals need to keep themselves up-to-date and relevant to their clients and communities. As suggested by Rizk (2008), in terms of moral theory, ethics training should structure an individual's internalised action-guided code.

\section{Research Methodology}

The research process started with literature review on the concepts of ethics and ethics education and training by previous authors. A questionnaire survey was then carried out to investigate perceptions on the issues of significance of ethics education and training for construction professionals. The questionnaire survey was conducted with construction professionals made up on architects, quantity surveyors and engineers from Malaysian construction industry players that are the clients, contractors and consultants involved with the design, project management and construction of projects in Malaysia. The public clients were made up of federal agencies, state corporation, city and local authority and statutory bodies; private clients from the developers; consultant firms from those registered with Board of Engineers, Board of Architects and Board of Quantity Surveyors, Malaysia; and contractor organisations from those registered with Construction Industry Development Board (CIDB) Malaysia under G7 to G4 categories. They are from the states of Selangor and Federal Territory of Kuala Lumpur, Malaysia, whereby these two states represent almost $70 \%$ of construction work carried out in Malaysia (CIDB, 2005a). This population frame for the survey presents an overall perception of major and different types of players on the research of ethics in the industry and avoiding bias. Also, since the subject matter is ethics, the clients are separated into public and private clients as the project objectives of these two types of clients normally differ; since private clients are often profit oriented as compared to public clients 
which may have an effect on the research results.

\section{Discussion of Results}

Out of 1,000 questionnaires sent out, 329 valid responses were received with a response rate of $33 \%$. The analyses carried out were frequency percentages to investigate the magnitude of demographic types of the respondents and perceptions of the respondents on the issues of significance of ethics education and training.

\subsection{Demography of Respondents}

The demographic data of the respondents were as follows. Quantity surveying dominated the professional discipline of respondents $(35 \%)$ followed by civil engineering (33\%). Other professional disciplines are architecture (15\%), mechanical engineering (10\%) and electrical engineering (7\%). Majority of respondents are trained in quantity surveying and civil engineering. In Malaysia, considering that quantity surveyors are normally involved in contractual and payment matters throughout the life of a project, and the civil engineers in the structural design and project management of projects at site-they give a fair representative of construction professionals in the industry for the research. There were also respondents from the mechanical and electrical engineering professions. This is relevant since they are involved with the mechanical and electrical design and installations for example, air-conditioning, lifts and electrical work, in the construction of a project. The respondents presented a fair distribution of consultants $(30 \%)$, public clients $(29 \%)$, contractors $(21 \%)$ and private clients $(20 \%)$. This provided credibility for the survey results and research objective since the voice on ethics is heard from the four main players of the construction industry.

\subsection{Ethics Education and Training}

The statements in the questionnaire are shown in Table 1.

Table 1. Ethics education and training

\begin{tabular}{l}
\hline Statements \\
ETHICS EDUCATION \\
Early education in ethics \\
Education in ethics should start from school. \\
Religious and moral education is important in setting high ethical standards. \\
Undergraduate ethics education \\
Ethics related subject is included in the course where I studied. \\
Ethics related subjects in the present construction and engineering curriculum at college/university are \\
inadequate and should be reviewed. \\
ETHICS TRAINING \\
I have attended ethics training courses after I have graduated (that is, whilst working) \\
There should be more ethics training at industry level imposed by professional institutions, by attending a set \\
number of hours/activities of CPD every year.
\end{tabular}

\subsubsection{Ethics Education}

1) Early education in ethics

Early education on ethics is considered significant as $96 \%$ of the respondents agreed that education in ethics should start from school. This showed that education from the elementary stage of an individual is important for future professionals' ethical behaviour, since ethical knowledge is a fundamental foundation of a sustainable society. On the religious essence, $96 \%$ of respondent construction professionals surveyed agreed that religious and moral education is important in setting high ethical standards. As Malaysia is a multi-religion country, the basic concerns of ethical teachings on individual character including what it means to be a good person and the rules that govern and limit our conduct concerning right and wrong is fundamental knowledge for any religion or belief.

2) Undergraduate ethics education

With regard to undergraduate ethics education, only $33 \%$ of the respondents said that ethics related subject was included in the courses where they studied. Further results showed that $89 \%$ of the respondents agreed that ethics related subjects in the present construction and engineering curriculum at college/university are inadequate and 
should be reviewed. Besides technical knowledge and competence, it is necessary that construction professionals have a broad based undergraduate education. Construction and engineering programs in Malaysia must demonstrate that their graduates have an understanding of professional and ethical responsibility, and ethical behaviour to face the industry and societal challenges.

\subsection{Ethics Training}

With regard to ethics training, only $28 \%$ of the respondents said they have attended ethics training courses after they have graduated (i.e. while working). Further results showed $85 \%$ of the respondents believed there should be more ethics training at industry level imposed by professional institutions, by attending a set number of hours/activities of CPD every year. Therefore, professional institutions in Malaysia should take up the challenge to endorse professional ethics substance by reviewing their training programs for their members. In order to inculcate ethical behaviour and practice among its members, professional institutions must take the lead in promoting ethics in the construction industry by conducting CPD ethics training. This training is needed to improve ethical awareness, a sense of responsibility, ethical decision-making skills and overall professional conduct of construction professionals.

\section{Conclusion}

In the attempt to reshape the future landscape of the construction industry in Malaysia, there is a need to address the increasing concern of ethical issues prevailing within the industry. The way forward is to improve ethics in the industry and it should start from the way we educate construction professionals by putting ethics in action. There is no doubt of the need for heightened standards of ethics for professionals in the Malaysian construction industry which include architects, quantity surveyors and engineers. In addition to understanding the concepts of ethics which define the rules and practices on responsible conduct between individuals, professions in the industry and the public; considerations to internalise and establish ethical values and conduct into the professionals are fundamental. Attention needs to focus on the benefits of enhancing students and professionals in workplace on the understanding of ethical perspectives and professionalism. As indicated from this research, the Malaysian construction industry should recognise that ethics education and training are significant to form the nucleus of the construction professionals' ethical setting to improve ethics in industry.

The educational setting is an ideal place to learn and practice ethics. Thus, ethics and moral education should be introduced and developed into individuals from a young age. This can be acquired at the early learning stage of elementary education at school. Further considerations on ethics have also established the significance of ethics education at colleges/universities undergraduate level and its positive outcomes for students. Ethics related courses should be introduced and emphasised in construction and engineering programs in colleges/universities to help mould the standards of the professional behaviour in the construction industry. The challenge for the Malaysian construction and engineering schools is to accept greater responsibility for ethics education. Changes in accreditation criteria which make ethics education compulsory will potentially elevate the prominence of instruction in ethics and societal context with the industry.

In order to establish ethical behaviour, all construction professionals should understand and apply ethics in everyday practice. Therefore, the process of learning ethics should not stop at colleges/universities but should continue during the professionals' working life. The main function of professional institutions is to regulate the members conduct and discipline in accordance with the rules set up by them. Leadership is also required from the professional institutions in Malaysia to develop a culture where ethics and practice can evolve. Understanding and applying ethics is crucial so as to establish what constitutes ethical behaviour on the part of the professionals; hence, professional institutions must be responsible to take up the challenge to endorse the ethics substance by conducting CPD ethics training for their members. This is to ensure adequate performance and ethical conduct of the professionals especially when faced with ethical issues and challenges of the industry locally and internationally. In order to encourage professional development, professional institutions should make CPD ethics training mandatory, not only for initial membership, but also for subsequent yearly renewal membership. This is to cultivate a habit of self-regulation and awareness to maintain high ethics through lifelong learning amongst the industry players.

Further research may be carried out concerning ethics education specifically in designing appropriate ethics curricula for undergraduate construction and engineering programs in Malaysia. The research may focus on the introduction, examination and application of applied professional ethics to the students in relation to construction practices for optimal exposure level to ethics. 


\section{References}

Abuznaid, S. A. (2009). Business ethics in Islam: The glaring gap in practice. International Journal of Islamic and Middle Eastern Finance and Management 2(4), 278-288. http://dx.doi.org/10.1108/175383909 11006340

Appelbaum, D., \& Lawton, S. V. (1990). Ethics and the Professions. Englewoods Cliff, NJ: Prentice-Hall.

Bergenhenegouwen, G. J. (1996). Professional code and ethics for training professionals. Journal of European Industrial Training, 20(4), 23-29. http://dx.doi.org/10.1108/03090599610117054

Birkhead, M., Sutherland, M., \& Maxwell, T. (2000). Core competencies required of project managers. South African Journal of Business Management, 31(3), 99-105.

Bishop, T. R. (1992). Integrating business ethics into an undergraduate curriculum. Journal of Business Ethics, 13, 291-299. http://dx.doi.org/10.1007/BF00872171

Bucciarelli, L. L. (2008). Ethics and engineering education. European Journal of Engineering Education, 33(2), 141. http://dx.doi.org/10.1080/03043790801979856

Candace, D. R. (2003). Professional ethics begin on the college campus. Chronicle of Higher Education, 50(4), 20-23.

Chakley, R. (1994). Professional conduct. London: RICS.

Chan, E. H. W., Chan, M. W., Scott, D., \& Chan, A. T. S. (2002). Educating the 21 st century construction professionals. Journal of Professional issues in Engineering Education and Practice, 44-51. http://dx.doi. org/10.1061/(ASCE)1052-3928(2002)128:1(44)

CIDB. (2005). Integrity forum on construction sector-strengthening image and enhancing professionalism. Keynote address, YB Dato' Seri S. Samy Velu, Minister of Works, Malaysia, September 12-13, Kuala Lumpur.

CIDB. (2007). Strategic recommendations for improving environmental practices in construction industry. Construction Industry Development Board Malaysia (CIDB), Kuala Lumpur.

Egbu, C. O. (2004). Managing knowledge and intellectual capital for improved organisational innovations in the construction industry, an examination of critical success factors. Engineering, Construction and Architectural Management, 11(5), 301-315. http://dx.doi.org/10.1108/09699980410558494

Eynon, G., Hill, N. T., \& Stevens, K. T. (1997). Factors that influence the moral reasoning abilities of accountants: Implications for universities and profession. Journal of Business Ethics, 16(12/13) 1297-1309. http://dx.doi.org/10.1023/A:1005754201952

Fan, C. N. L., \& Fox, P. W. (2005). Ethical Issues in the construction industry. Hong Kong Construction Industry Institute, Hong Kong.

FMI/CMAA. (2004). Survey of Construction Industry Ethical Practices and Issues, Management Consultant for the Construction Industry and Construction Management Association of America (CMAA). Retrieved March 2, 2010, from http://www.fminet.com/global/Articles/EthicalPracticeSurvey.pdf

Fox, P. W., \& Skitmore, R. M. (2003). Developing the Hong Kong construction industry, Knowledge Construction. Proceedings of Joint International Symposium of CIB Working Commissions, W55, W65 and W107, October 22-24, Singapore, Department of Building, National University of Singapore.

Freidson, E. (1973). The professions and their prospects. London: Sage Publications.

Fryer, B. G. (1997). The Practice of Construction Management. Oxford: Blackwell Science.

Fuchs, C., \& Hofkirchner, W. (2003). Self-organisation, knowledge and responsibility. Kybenetes, 34(1/2), 241-260. http://dx.doi.org/10.1108/03684920510575825

Gautschi, F. H., \& Jones, T. M. (1998). Enhancing the ability of business students to recognise ethical issues: An empirical assessment of the effectiveness of a course in business ethics. Journal of Business Ethics, 17(2), 205-216. http://dx.doi.org/10.1023/A:1005740505208

Glenn, J. R. (1992). Can business and society course effect the ethical judgement of managers? Journal of Business Ethics, 11(3), 217-233. http://dx.doi.org/10.1007/BF00871969

Grimshaw, B. (2001). Ethical issues and agendas. Facilities, 19(1/2), 43-51. http://dx.doi.org/10.1108/02632770 110362794 
Guttmann, D. (2006). Ethics in Social Work: A Context of Caring. Philadelphia, PA: The Haworth Press.

Halfond, J. (1990). Should business schools be Sunday schools? Business and Society Review, 72, 52-54.

Herkert, J. R. (2000). Engineering ethics education in the USA: Content, pedagogy and curriculum. European Journal of Engineering Education, 25(4), 303-314. http://dx.doi.org/10.1080/03043790050200340

Hiltebeitel, K. M., \& Jones, S. K. (1992). An assessment of ethics instruction in accounting education. Journal of Business Ethics, 11(1), 37-46. http://dx.doi.org/10.1007/BF00871990

Ho, M. F. C., \& Ng, C. W. V. (2003). Quantity surveyors' background and training, and their ethical concepts, conceptions and interests considerations. Construction Management and Economics, 21, 43-67. http://dx.doi.org/10.1080/0144619032000065117

Hong Kong Ethics Development Centre (HKEDC). (1996). Ethics for professionals (Architecture, Engineering and Surveying): A resource portfolio for Hong Kong Universities. Hong Kong Ethics Development Centre, Hong Kong.

Hong Kong Ethics Development Centre (HKEDC). (2003). Ethics for Construction Professionals-A resource portfolio for Hong Kong Universities. Independent Commission against Corruption (ICAC) New Territories, Hong Kong.

Institute of Integrity Malaysia (IIM). (2004). National Integrity Plan (NIP). Kuala Lumpur, Malaysia.

Jackson, B. (2004/2005). The perceptions of experienced construction practitioners regarding ethical transgressions in the construction industry. The International Journal of Construction Education and Research, 1(2), 112-128.

Jamal, K., \& Bowie, N. E. (1995). Theoretical considerations for a meaningful code of professional ethics. Journal of Business Ethics, 14, 702-714. http://dx.doi.org/10.1007/BF00872324

Johnson, D. G. (1999). Ethical issues in Engineering. Englewood Cliffs, NJ: Prentice-Hall.

Kerr, D. S., \& Smith, L. M. (1995). Importance of and approaches to incorporating ethics into the accounting classroom. Journal of Business Ethics, 14(12), 987-995. http://dx.doi.org/10.1007/BF00872114

Koehn, D. (1994). The ground of professional ethics. London: Routledge.

Le Roux, G. K., Nkado, R. N., \& Mbachu, J. I. (2004). Critical determinants of successful professional practice. Proceedings of International Construction Research Conference of the Royal Institution of Chartered Surveyors, September 7-8, Leeds Metropolitan University. UK.

Lewis, M. (2001). Islam and accounting. Accounting Forum, 25(2), 103-127. http://dx.doi.org/10.1111/14676303.00058

Martin, M. W., \& Schinzinger, R. (1996). Ethics in Engineering (3rd ed.). New York: McGraw-Hill.

Martin, M. W., \& Schinzinger, R. (2005). Ethics in Engineering (4th ed.). New York: McGraw-Hill.

McDowell, B. (1991). Ethical conduct and the professional's dilemma. New York, NY: Quorum Books.

Orme, G., \& Ashton, C. (2003). Ethics-a foundation competency. Industrial and Commercial Training, 35(5), 184-190. http://dx.doi.org/10.1108/00197850310487313

Pearl, R., Bowen, P., \& Makanjee, N. (2005). Professional ethics in the South African construction industry-a pilot study. Proceedings of Queensland University of Technology Research Week International Conference, July 4-8, Queensland University of Technology, Brisbane, Australia.

Poon, J. (2004). An investigation of the differences in ethical perceptions among construction managers and their peers. Proceedings of Association of Researchers in Construction Management (ARCOM) Conference, Edinburgh, Heriot-Watt University, UK.

Rick, B. (2005). The industry need: A code of conduct. Engineering News Record, 254(4), 51.

RICS. (1993). Guide and rules to the test of professional competence. London: Building Surveying Division.

Rizk, R. R. (2008). Back to basics: An Islamic perspective on business and work ethics. Social Responsibility Journal, 4(1/2), 246-254. http://dx.doi.org/10.1108/17471110810856992

Robertson, H. D. (1987). Developing ethics education in the construction education program. Proceedings of 23rd Annual Conference Associated Schools of Construction, Purdue University, Indiana.

Schemerhorn, J. R. (2008). Management. Hoboken, NJ: Wiley. 
Self, D. J., \& Ellison, E. M. (1998). Teaching engineering ethics: Assessment of its influence on moral reasoning skills. Journal of Engineering Education, 87(1), 29-34. http://dx.doi.org/10.1002/j.2168-9830.1998. tb00319.x

Suen, H., Cheung, S., \& Mondejar, R. (2007). Managing ethical behaviour in construction organisations in Asia: How do the teachings of Confucianism, Taoism and Buddhism and globalization influence ethics management? International Journal of Project Management, 25, 257-265. http://dx.doi.org/10.1016/j. ijproman.2006.08.001

Sunthonkanokpong, W. (2011). Future global visions of engineering education, Engineering Procedia, 8, 160-164. http://dx.doi.org/10.1016/j.proeng.2011.03.029

Turner, D., \& Crawford, M. (1992). Managing current and future competitive performance: The role of competence. Australian Graduate School of Management, Centre for Corporate Change, 1-26.

Vee, C., \& Skitmore, M. (2003). Professional ethics in the construction industry. Engineering, Construction and Architectural Management, 10(2), 117-127. http://dx.doi.org/10.1108/09699980310466596

Velasquez, M. G. (2009). Business Ethics: Concepts and Cases. New York: Prentice- Hall.

Webster, G. (1991). The training and development profession. In J. Gower (Ed.), Handbook of training and development. Gower, Aldershot.

Whitbeck, C. (1998). Ethics in Engineering Practice and Research. Cambridge: Cambridge University Press. http://dx.doi.org/10.1017/CBO9780511806193

\section{Copyrights}

Copyright for this article is retained by the author(s), with first publication rights granted to the journal.

This is an open-access article distributed under the terms and conditions of the Creative Commons Attribution license (http://creativecommons.org/licenses/by/3.0/). 